\title{
SŁOWA POGRANICZA \\ (NA MATERIALE GWAROWYM WSCHODNIEJ LUBELSZCZYZNY) ${ }^{1}$
}

\author{
Halina Pelcowa \\ Uniwersytet Marii Curie-Skłodowskiej w Lublinie \\ ORCID: 0000-0002-1380-4943
}

\begin{abstract}
Streszczenie. Przedmiotem rozważań jest słownictwo usytuowane geograficznie, mentalnie i historycznie na obszarze Lubelszczyzny wschodniej, rozpatrywane w relacji nazwy do desygnatu i zmian cywilizacyjno-kulturowych wynikających z procesów globalizacyjnych. Są to: 1) nazwy genetycznie wschodniosłowiańskie, a więc wyrazy (lub ich znaczenia) pochodzenia ukraińskiego, białoruskiego; 2) „geograficzne dialektyzmy kresowe” wspólne dla gwar pogranicza wschodniego po obu stronach Bugu, przy czym wspólnota ta wynika wyłącznie z sąsiedztwa terytorialnego; 3) wyrazy funkcjonujące w świadomości językowej mieszkańców wsi jako przynależne do określonej nacji.
\end{abstract}

Słowa klucze: słowo, pogranicze, gwary, Lubelszczyzna

Zagadnienie kontaktów językowych sąsiadujących ze sobą i stykających się bezpośrednio różnych gwar, należących do pokrewnych grup językowych, wywodzących się z jednego pnia, czyli języka prasłowiańskiego, jest - podobnie jak sprawa pokrewieństwa i odrębności językowych w ogóle - zagadnieniem skomplikowanym i niejednoznacznym interpretacyjnie. Do grupy takich problemów należy funkcjonowanie słownictwa na pograniczu polsko-wschodniosłowiańskim, które uwikłane w różnego rodzaju uwarunkowania i zależne od czynników pozajęzykowych (historycznych, administracyjnych, politycznych, religijnych, etnicznych, osadniczych, etnograficznych, gospodarczych), w istotny sposób kształtuje stopień spójności i jednolitości badanego regionu z jednej strony, ale też staje się czynnikiem sprawczym niezwykłej różnorodności i braku spoistości geograficznej z drugiej.

Diachroniczne i synchroniczne ujęcia sytuacji językowej na pograniczu polsko-wschodniosłowiańskim, w tym leksyki gwarowej, przybliżają m.in. pra-

NARoDowY Program
ROZWOJU HUMANISTKI Praca realizowana w ramach Programu Ministra Nauki i Szkolnictwa Wyższego pod nazwą „Narodowy Program Rozwoju Humanistyki” w latach 2018-2023 nr projektu 0125/NPRH7/H11/86/2018. 
ce Hryhorija Arkuszyna ${ }^{2}$, Feliksa Czyżewskiego ${ }^{3}$, Karola Dejny ${ }^{4}$, Sławomira Gali i Beaty Gali-Milczarek ${ }^{5}$, Haliny Karaś 6 , Anny Kosteckiej-Sadowej ${ }^{7}$, Józefa Kościa $^{8}$, Władysława Kuraszkiewicza ${ }^{9}$, Zofii Kurzowej ${ }^{10}$, Michała Łesiowa ${ }^{11}$, Jana Mazura $^{12}$, Haliny Pelcowej ${ }^{13}$, Alicji Pihan-Kijasowej ${ }^{14}$, Janusza Riegera ${ }^{15}$, Doroty Rembiszewskiej i Janusza Siatkowskiego ${ }^{16}$, Bogdana Walczaka ${ }^{17}$, Stefana Warchoła ${ }^{18}$, a także atlas gwar ukraińskich ${ }^{19} \mathrm{i}$ atlas gwar białoruskich ${ }^{20}$. W niniejszym artykule skupimy się, z konieczności, tylko na niektórych aspektach leksyki pogranicza, rozpatrywanej $\mathrm{w}$ relacji nazwy do desygnatu i zmian cywilizacyjno-kulturowych wynikających z procesów globalizacyjnych, związanych $\mathrm{z}$ grupowaniem się i funkcjonowaniem na terenie regionu lubelskiego wyrazów wspólnych dla gwar polskich i ukraińskich (częściowo białoruskich). Wydzielimy trzy grupy leksyki, wypełniającej zarówno przestrzeń geograficzną, jak i mentalną, zamkniętą w świadomości językowej i kompetencji komunikacyjnej mieszkańców wsi wschodniej części Lubelszczyzny ${ }^{21}$. Są to wyrazy wspólne dla gwar polskich i wschodniosłowiańskich, w tym:

1) nazwy genetycznie wschodniosłowiańskie, a wśród nich wyrazy (lub ich znaczenia) wspólne dla:

gwar polskich, ukraińskich i białoruskich, np. bettun // bołtun 'jajko zepsute, śmierdzące', cedzilko 'szmatka do przecedzania mleka', cepilno 'część

2 Г. Аркушин, Словник західниополіських говірок, Луцьк 2000. Wszechstronny obraz poznawczy haseł słownikowych oraz wartość naukową dyferencyjnego opracowania H. Arkuszyna w zakresie studiów porównawczych nad leksyką pogranicza polsko-ukraińskiego znajdziemy w artykule F. Czyżewskiego, Kilka uwag leksykograficznych (na marginesie ,Stownika gwar zachodniopoleskich” Hryhorija Arkuszyna), „Poznańskie Studia Polonistyczne. Seria Językoznawcza”, vol. 25 (45), nr 1, 2018, s. 33-44.

3 F. Czyżewski, Atlas gwar polskich i ukrainskich okolic Włodawy, Lublin 1986; idem, $O$ problemach interferencji językowej $w$ ukraińskich gwarach wschodniej Lubelszczyzny, „Z Polskich Studiów Slawistycznych”, seria VII, Językoznawstwo, Warszawa 1988, s. 87-93.

K. Dejna, W sprawie tzw. dialektów kresowych, „, Język Polski” LXIV, 1984, s. 51-57.

S. Gala, B. Gala-Milczarek, Jeszcze w sprawie metodyki badań pogranicza językowego, [w:] Spotkania polsko-ukraińskie. Język - Kultura - Literatura, red. H. Pelcowa, Chełm 2006, s. $141-149$.

$6 \quad$ H. Karaś, Język polski pogranicza litewsko-łotewsko-białoruskiego w świetle frekwencji cech językowych, Warszawa 2017.

7 A. Kostecka-Sadowa, Rzeczownikowe zapożyczenia wschodniostowiańskie $w$ gwarach polskich, Kraków 2015.

$8 \quad$ J. Kość, Polszczyzna poludniowokresowa na polsko-ukraińskim pograniczu językowym w perspektywie historycznej, Lublin 1999.

9 W. Kuraszkiewicz, Przegląd gwar województwa lubelskiego, [w:] Monografia statystyczno-gospodarcza województwa lubelskiego, t. 1, Lublin 1932, s. 273-324.

10 Z. Kurzowa, Polszczyzna Lwowa i kresów poludniowo-wschodnich do 1939 roku, Warszawa-Kraków 1983; eadem, O polskich dialektach kresowych, „Język Polski” LXV, 1985, s. $98-108$.

11 M. Łesiów, Polsko-ukraińskie oboczności leksykalne w gwarach pogranicza, „Z Polskich Studiów Slawistycznych", seria V, Językoznawstwo, Warszawa 1978, s. 279-286. 
cepów, którą trzyma się w ręku', chusty 'brudnabielizna przeznaczona do prania', jen' 'szron na drzewach', kociuba 'narzędzie do wygarniania węgli z pieca chlebowego', koromysto // koromysta 'drążek do noszenia na ramionach wiader z wodą', kosowica 'sianokosy', lepiech 'tatarak zwyczajny: Acorus calamus', letuczaja // letuszczaja mysz 'nietoperz, zwierzę z rzędu Chiroptera', młodziwo // mołodziwo // mołoziwo 'pierwsze mleko, które krowa daje po ocieleniu', ożyny 'jeżyny - owoce rośliny Rubus', okorak 'stara, zdarta

12 J. Mazur, Gwary okolic Biłgoraja, t 1: Fonologia, Wrocław 1976; t. 2: Fleksja, Wrocław 1978.

13 H. Pelcowa, Mazowizmy leksykalne w gwarach Lubelszczyzny, Lublin 1994; eadem, Gtos $w$ dyskusji nad gwarami przejściowymi i mieszanymi wschodniej Polski, [w:] Studia nad polszczyzna kresowa, t. 7, red. J. Rieger, Wrocław 1993, s. 159-169; eadem, Stownictwo wschodniosłowiańskie $w$ gwarach Polski środkowo-wschodniej $w$ świetle związków językowych polsko-ukraińskich, [w:] Ze studiów nad gwarami wschodniostowiańskimi w Polsce, „Rozprawy Slawistyczne" 12, 1997, red. F. Czyżewski, M. Łesiów, s. 189-211; eadem, Interferencje leksykalne w gwarach Lubelszczyzny, Lublin 2001; eadem, Polsko-białorusko-ukraińskie paralele leksykalne w świetle kulturowego dziedzictwa prastowiańskiego, [w:] Język i kultura biatoruska w kontakcie z sasiadami, red. E. Smułkowa, A. Engelking, Warszawa 2001, s. 141-151; eadem, Kulturowa wartość słownictwa $w$ gwarach pogranicza (na przykładzie gwar wschodniolubelskich), [w:] Język i kultura na pograniczu polsko-ukraińsko-białoruskim, red. F. Czyżewski, red., Lublin 2001, s. 43-59; Stownictwo kresowe jako element tożsamości pogranicza (na materiale gwar Lubelszczyzny), [w:] Polskie dziedzictwo językowe na dawnych Kresach. Język polski dawnych Kresów Wschodnich, t. 5, red. E. Dzięgiel, K. Czarnecka, D. Kowalska, Warszawa 2012, s. 257-264; eadem, Dziedzictwo leksykalne pogranicza polsko-wschodniostowiańskiego w interpretacji mieszkańców wsi, [w:] Pogranicza słowiańskie w opisach językoznawczych. W 110 rocznice urodzin Profesora Władysława Kuraszkiewicza (1905-1997), red. F. Czyżewski, M. Olejnik, A. Pihan-Kijasowa, Lublin-Włodawa 2015, s. 91-98.

14 A. Pihan-Kijasowa, Polszczyzna Kresów Wschodnich - efekt pogranicza językowego, [w:] Pogranicza stowiańskie w opisach językoznawczych. W 110 rocznicę urodzin Profesora Władystawa Kuraszkiewicza (1905-1997), red. F. Czyżewski, M. Olejnik, A. Pihan-Kijasowa, Lublin-Włodawa 2015, s. 97-104.

15 J. Rieger, Interferencje ukraińskie w gwarach polskich na Podolu, [w:] Interferencje w językach i dialektach stowiańskich, red. E. Umińska-Tytoń, Łódź 1997, s. 134-140; idem (red.), Stownictwo kresowe. Studia i materiaty, Warszawa 2008.

16 D. Rembiszewska, J. Siatkowski, Pogranicze polsko-wschodniostowiańskie. Studia wyrazowe, Warszawa 2018.

17 B. Walczak, Pogranicze polsko-wschodniostowiańskie od średniowiecza do dziś, [w:] Pogranicza słowiańskie w opisach językoznawczych. W 110 rocznicę urodzin Profesora Władysława Kuraszkiewicza (1905-1997), red. F. Czyżewski, M. Olejnik, A. Pihan-Kijasowa, LublinWłodawa 2015, s. 149-156.

18 S. Warchoł, Specyfika gwar mieszanych i przejściowych na terenach etnicznie zróżnicowanych, „Rozprawy Slawistyczne” 5, 1992.

19 Атлас украӥнської мовы, t. 1-2, Киїv 1984-1988.

20 Лексічны атлас беларускіх хародных гаворак, t. 1-2, Мінск 1993-1994.

21 Analizowany materiał został zebrany przez autorkę artykułu w latach 2000-2019 w 50 wsiach na obszarze wschodniej części obecnego województwa lubelskiego, zamkniętej od zachodu linią: Biłgoraj-Krasnystaw-Lubartów-Biała Podlaska. Informatorami byli mieszkańcy wsi, mający w chwili udzielania informacji ponad 70 lat. 
miotła', raby 'różnobarwny', wyszki 'strych nad oborą', siny 'niebieski', sud$k i$ 'wąskie przejście między dwoma blisko siebie stojącymi budynkami', ścil 'sufit drewniany', ślozy 'łzy', tok 'miejsce w stodole, gdzie młóci się zboże', zezula i formy pokrewne 'ptak, kukułka, Cuculus canorus';

gwar polskich i ukraińskich, np. bodziak // bodak // bodiak 'chwast - oset, Cirsium arvense', chmielina 'zielona naziemna część krzaka ziemniaków', dryga // drygi // drygla // drygle 'galareta z nóżek wieprzowych', huby 'nazwa ogólna grzybów, oprócz prawdziwka', kałatuszka 'tłuczek w maślniczce', kartoflinie 'zielona naziemna część krzaka ziemniaków', krynica 'źródło', makutra 'gliniana miska do ucierania maku', maniak 'torba do karmienia koni przy wozie', pituch // pieweń 'kogut - samiec kury domowej', zolnik 'dawne drewniane naczynie służące do zaparzania w ługu brudnej bielizny';

dla gwar polskich i białoruskich, np. berdo 'grzebień do przybijania wątku w warsztacie tkackim', kruczek 'pogrzebacz', opołonik 'duża drewniana łyżka kuchenna', polica 'odkładnica pługa', radno 'płachta do siania zboża', wołoszka 'chwast - chaber, Centaurea cyanus', uziory 'dolna część snopa', urzech 'ominięty przez nieuwagę oracza kawałek pola';

wyrazy innego pochodzenia, ale przeniesione do gwar polskich z gwar wschodniosłowiańskich lub za ich pośrednictwem, w tym lituanizmy, orientalizmy, np. kulsza 'biodro u człowieka', żłukto 'dawne drewniane naczynie służące do zaparzania w ługu brudnej bielizny', kułak 'pięść', kaczan 'głąb kapusty';

2) „geograficzne dialektyzmy kresowe" ${ }^{22}$ wspólne dla gwar pogranicza wschodniego po obu stronach Bugu, przy czym wspólnota ta wynika przede wszystkim z sąsiedztwa terytorialnego, np. człowieczek 'źrenica oka', chaby // chabory 'żebra u człowieka', hak // haczyk 'pogrzebacz', jama 'piwnica poza domem' i 'piwnica pod domem', karczunek 'pole po wykarczowanym lesie', kidać 'rzucać', kopanice 'płozy sań, korbon 'płachta zawieszona w polu na kijach, zastępująca kołyskę', koza 'warkocz', loch 'piwnica poza domem' i 'piwnica pod domem', tatać // latacz 'kaczeniec, Caltha palustris L.', pusz$\mathrm{ka}$ 'część środkowa koła wozu', rozkałatać 'rozmieszać mąkę z wodą', snozy // snózki 'poprzeczne listwy łączące belki bron', sosznik 'ostrze w płużku do oborywania ziemniaków', świerzupa 'chwast - gorczyca polna, Sinapis arvensis', żmykać 'prać w rękach'. Zaliczymy tu zarówno słownictwo występujące $\mathrm{w}$ różnych językach słowiańskich, stanowiące wspólne dziedzictwo prasłowiańskie (np. jama, tatać), jak i wyrazy innego pochodzenia, np. germanizmy leksykalne ( $h a k$, haczyk, loch), będące tzw. pożyczkami geograficznymi, z tym że kierunek zapożyczeń może być obustronny, z gwar polskich do ukraińskich czy białoruskich i odwrotnie;

\footnotetext{
22 Zagadnienie to zostało omówione w opracowaniach: H. Pelcowa, Stownictwo wschodniosłowiańskie..., s. 189-211; eadem, Interferencje..., s. 63-67. Tam też obszerna bibliografia.
} 
3) wyrazy niepodlegające zasygnalizowanemu podziałowi, a rozpatrywane na płaszczyźnie mentalnej, z uwzględnieniem świadomości językowej mówiących i ich kompetencji komunikacyjnej, funkcjonujące w odczuciu mieszkańców wsi jako przynależne lub nie do określonej nacji narodowej. $\mathrm{Na}$ pograniczach zmiany w języku mieszkańców wsi uwarunkowane są nie tylko wzajemnymi wpływami jego poszczególnych odmian (gwarowej, regionalnej, potocznej i ogólnopolskiej), lecz także oddziaływaniem na siebie różnych języków etnicznych. Wynikiem tego procesu jest nakładanie się systemów i wzajemne przenikanie elementów do nich należących (np. polskiego i ukraińskiego na wschodzie regionu lubelskiego lub polskiego i białoruskiego w części północnowschodniej), a także poczucie przynależności lokalnej, regionalnej i świadomość własnej tożsamości, przejawiającej się w „naszości” i „swojskości”, np.:

A co tam mówić polskie czy ukraińskie, to przecież nasze z dziada pradziada, ja tu urodzony i tu całe życie, i tak zawsze mówit i mówie lepiech, bełtun, bodiak, no bo jak inaczy (Świerże, powiat chełmski);

To Ruskie kiedyś te kutie gutuwali, a potem to i my, bo to byto dobre, to taka nasza potrawa wigilijna, taka stad (Kostomłoty, powiat bialski);

Pu polsku to oset, a po ukraińsku bodziak, powi sie tak i tak (Staw, powiat chełmski);

Bodziak czy toset to wszystko jedno, ja tam nie wim jakie to, polskie czy tukraińskie, to nasze, tutejsze i już, my tak zawsze mówili i jeszcze moje dziadek tak mówili, to i tak ma być (Leszczany, powiat chełmski).

Ponadto, występowanie niektórych wyrazów gwarowych zarówno polskich, jak i wschodniosłowiańskich jest podyktowane koniecznością komunikacyjną. Brak odpowiedniej nazwy dla ściśle oznaczonego desygnatu może prowadzić do nieporozumień, a często nazwa jest przenoszona wraz z przedmiotem czy zjawiskiem, które określa, i jej zastępowanie inną prowadzi do różnic znaczeniowych albo jest niemożliwe, bo nie ma odpowiedniego desygnatu. Dotyczy to głównie tzw. pożyczek rzeczowych, nieprzekładalnych na inny język, np. hołoble 'dyszle podwójne w jednokonnym typie wozu', słoducha // sołoducha 'rodzaj gęstej zupy gotowanej na zakwasie z mąki gryczanej, żytniej lub pszennej', korowaj 'tradycyjne, obrzędowe ciasto weselne', kutia 'potrawa wigilijna z pszenicy, maku i miodu'.

Przyjrzyjmy się zasięgom niektórych z wymienionych wcześniej wyrazów i relacjom zachodzącym na linii nazwa : desygnat ${ }^{23}$, zależnym od trwałości zarówno nazwy, jak i desygnatu, ich żywotności i powszechności funkcjonalnej.

23 J. Bartmiński, Czym zajmuje się etnolingwistyka?, [w:] Stereotypy mieszkaja w języku. Studia etnolingwistyczne, Lublin 2007, s. 32-39; W. Doroszewski (red.), Stownik jezyka polskiego, t. 1, Warszawa 1958, s. XXVII; H. Pelcowa, Nazwa i desygnat w zmieniającej się rzeczywisto- 
Bodziak // bodak // bodiak 'chwast - ostrożeń polny, Cirsium arvense 24 . Chwast ten określany jest ogólnopolską nazwą oset i jej gwarowym synonimem bodziak (bodak, bodiak), które charakteryzują zarówno całą roślinę, np.:

Bodziak no można puwiedzić, że to takie ziele, chwast, oset taki, ma kwiatki i kolce, ma takie kolace te kwiatki i tak kole, i tak sie czepia wszystkiego (Hołowno, powiat parczewski);

Bodak to chwast o klujacych liściach $i$ łodygach (Łukowa, powiat biłgorajski);

Bodiak to po przekwitnięciu ma taki szary puch i to tak sie rozlatuje z wiatrem, i potem cate pole z tym bodiakiem jest (Kopyłów, powiat hrubieszowski),

wskazują na jej szkodliwość, np.:

Bodak to kwitnie tak różowo, fiolytowo, ale to paskudne ziele (Wólka Tarnowska, powiat chełmski);

Budaki pole całe zawalili i zboża ni możno wykosić (Przewodów, powiat hrubieszowski),

uwypuklają cechy charakterystyczne tkwiące w nazwie, np.:

Bodziak, bo bodzie tymi kolcami (Ostrów, powiat chełmski);

Bodak w polu rośnie, kolacy taki, kole, tak bodzie (Rachanie, powiat tomaszowski);

To un taki bodzacy jest można puwiedzić, tak bodzie, i to bodziak (Teresin, powiat chełmski),

ale też lokalizują mentalnie i tożsamościowo, np.:

My zawsze bodziak mówili i jeszcze moje dziadek i babcia tak mówili, to $i$ niech tak zustanie, bo to tradycja nasza, z dziada pradziada una (Siedliska, powiat tomaszowski);

To u nas rośnie tyn oset, bodziak tyn, bo oset to więcy z polska, a bodziak to znowu z ukrainska, ale to jest to samo (Orchówek, powiat włodawski). Kociuba 'narzędzie służące do wygarniania węgli z pieca chlebowego' 25 . Kociuba to nazwa powszechnego narzędzia potrzebnego przy domowym wypieku chleba, postrzegana ze względu na charakter desygnatu i jego użyteczność, np.:

Kociuba to drewniana $i w$ dole mytalowa, takie jak motyka do wygarniania żaru z pieca chlebowego (Grabowiec, powiat zamojski);

ści wiejskiej, [w:] Odkrywanie stowa - historia i wspótczesność, red. U. Sokólska, Białystok 2015, s. 551-568.

24 F. Czyżewski, Atlas..., mapa 115; D. Rembiszewska, J. Siatkowski, op. cit., s. 65-69; H. Pelcowa, Mazowizmy..., s. 84, mapa XII; eadem, Interferencje..., s. 139, mapa 33; eadem, Stownik gwar Lubelszczyzny, t. 5: Świat roślin, Lublin 2017, s. 79-80, 547, mapa 26.

$25 \quad$ F. Czyżewski, Atlas..., mapa 73; H. Pelcowa, Mazowizmy..., s. 84, mapa XII; Interferencje.., s. 181, mapa 75; Stownik gwar Lubelszczyzny, t. 6: Pokarmy, Lublin 2019, s. 252-253, 691, mapa 42. 
Wegiel musiat być wyciagnięty, musiała być kuciuba. Inne kogo stać to blaszane mieli, a inne drewniane kuciube mieli (Dobryń, powiat bialski); Rozgartato sie wegle kociubo po calym piecu, bo musiat sie trzon napalić, jak poleży przesuwto sie szyberek $i$ to kociubo wygartato sie węgle do czyściutka (Ortel Królewski, powiat bialski);

W piec wsadzali na tupacie, byta kuciuba do wygartania z ognia, ciasto wykatulali, żyby była ładna bochynka i przyżygnali, żeby sie udat, i ciszyli sie, że chlib bedo mieli (Susiec, powiat tomaszowski).

Koromysło 'drążek do noszenia na ramionach wiader z wodą' ${ }^{26}$.

Koromysło zlokalizowane na północy i koromysła na południu Lubelszczyzny przybliżają z kolei dawny obraz czerpania i noszenia wody ze studni i z krynicy, np.:

Koromysta to urzqdzenie na wode nosić, no to tak, kij i takie du czypiania haczyki, i to na ramiona brat $i$ wody dwa wiader i niós (Barbarówka, powiat chełmski);

Na kurumystach wode $w$ wiadrach nusili z krynicy (Rogatka, powiat chełmski);

Studniów ni byto tak dużo jak tera, no to trza byto sobie ty wody nanieść czasem z dalsza, u nas byto z pót kilometra, Szło sie z kurumysłami, i zakładało sie wiadro z jedny $i$ wiadro $z$ drugi struny $i$ na kark tu, na ramiona, $i$ sie niesto (Miętkie, powiat hrubieszowski).

Zezula (zazula // zezulka // zazulka) 'ptak leśno-parkowy, o upierzeniu popielatym, spodem białym w czarne pręgi, Cuculus canorus' ${ }^{27}$.

Zezula (zazula //zezulka // zazulka) wpisuje się w kontekst kulturowo-obyczajowo-wierzeniowy i przemiany cywilizacyjne odbite w języku, np.:

A zezula, no kukutka, bo to i kukutka sie nazywo, no to taki ptok, co podrzuco drugim swoje jajka i kuko łod wczesny wiosny do Pietra i Pawła, a potem to mówio, że sie w jastrzębia przemienia (Szczebrzeszyn, powiat zamojski);

O zezula mie okukala z piniędzmi i mówie do mojego starego, bedzie dobrze w tym roku sie działo (Laszczówka, powiat tomaszowski);

Zezula to jak kuko to przepowieda różne rzeczy, przeważnie pannom czy prędko męża znajdo (Zaporze, powiat zamojski);

To byta zezula, ale teraz nikt tak nie powie, tera kukutka (Majdan Nepryski, powiat biłgorajski);

26 F. Czyżewski, Atlas..., mapa 103; D. Rembiszewska, J. Siatkowski, op. cit., s. 138-143; H. Pelcowa, Interferencje..., s. 173, mapa 67; Stownik gwar Lubelszczyzny, t. 6: Sad i ogród warzywny. Budownictwo i przestrzeń podwórza, Lublin 2016, s. 301, 539, mapa 42.

27 Общеславянский лингвиситческий атлас. Выпуск I. Щивотный мир, Москва 1988, karta 21; H. Pelcowa, Stownik gwar Lubelszczyzny, t. 3: Świat zwierząt, Lublin 2015, s. 404407, 446, mapa 19. 
Zezula to kuka od wiosny do kuńca czerwca, do Piotra i Pawta, ale tak si schowa, że kukanie styszysz, a ptaka ni widać, takie to madre (Zosin, powiat hrubieszowski);

Między sobo to mówim zezula kuko, ale już przy obcych to kukutka kuko. A mlode to nawet ni wiedzo co to takiego, bo i dzieś tu nas wygineli te zezule, rzadko już kukajo (Rogatka, powiat chełmski).

Zolnik 'dawne drewniane naczynie służące do zaparzania w ługu brudnej bielizny'28.

Zolnik, jako nazwa dawnego naczynia, wskazuje na przeszłość związaną $z$ desygnatem już nieznanym, a jedynie przywoływanym we wspomnieniach. Najstarsi mieszkańcy wsi Lubelszczyzny wschodniej charakteryzują jego wygląd, ale też użyteczność i przydatność na co dzień, np.:

Zolnik to taka beczka, z tym że była na nogach. I robiło sie tug, w tugu sie prało bilizne, pościelowo i usubisto. Lało sie do beczki goraco wode, a paliło sie w kuchni drzewem, najlepiej było usikowym, późnij sie wybierało popiót, przysiwało sie przez jakiś tam przetak, wsypywało sie do takiego specjalnego woreczka ten popiót $i$ wktadało sie do tego wrzatku, do tego zulnika (Borowiec, powiat biłgorajski);

Dawno pralków nie byto, a prać mus byto, to byli te zulniki. To naczynie takie kręgle, tako balyja, ale z drewna, na trzech nogach stata, tu z boku dziura byta, dziure zatkali tam czym, szmat natożut, lug z popiołu zrubili, posypali tym tugiem $i$ wodo goraco przeliwali. Tak pare razy, potem dziure odetkal, woda wyleciała i znów kilka razy to samo, jaż woda czyściutko była, i te szmaty zrubili sie bilutkie. A potem baby do rzyki (Kopyłów, powiat hrubieszowski),

$W$ zolnikach sie zuliło, no bo to nie było tak żadnych proszków, niczego, tyko sypato sie, przykrywało sie taki zolnik, naukładało sie wszystkiego tam, no któro tam do prania, bo byto uprane raz, późnij już drugi raz. Jak sie miało prać wktadało sie $w$ tyn zolnik i na wirzch nakrywato sie. Taka beczka była i tam sie sypało popiół taki z drzewa, jak było palone, i późnij trzeba było wode gotować, i w tyn popiół lać na wierzch, no i tam byt taki czop ze stumy zrubiony i ta woda ścikata. No ta woda goraca, no to już wiadomo byto no, że to sie zoli. I stało przez noc w tym wszystkim, a na drugi dziń ustygło w tym zulniku i dopiro sie na wode to kijanko, du krynicy nieśli (Dubienka, powiat chełmski);

Bielizna byta lniana, pierwsze sie jo raz przeprało, później sie jo kładto $w$ taki zolnik, take beczke, i tam byt czop taki zrobiony i popiót na wierzch nasypany, i na ten popiót lana była woda, i to sie tak aż przelało do spodu,

\footnotetext{
28 H. Pelcowa, Mazowizmy..., s. 145, mapa 38, s. 85, mapa XIII; eadem, Interferencje..., s. 168 , mapa 62.
} 
to miało być gorace, woda goraca na spodzie miała być i później dopiero na drugi dzień wyjmało sie, i prało sie (Osiczyna, powiat zamojski).

Czlowieczek 'źrenica oka'29.

Człowieczek w odniesieniu do części oka niesie konotacje obyczajowo-kulturowe $\mathrm{z}$ jednoczesnym uwypukleniem zalet i wad człowieka, np.:

Kto powi źrenica, a kto inny paninka, laleczka, czluwieczek, to jest to samo, ale jak sie mówi paninka, laleczka to tak przyjemnie, bo to z uczciwym czluwiekiem ruzmawia, patrzy mu prosto $w$ oczy i śliczno panienke widzi, tako laleczke, a jak czluwieczek to już nie taki to uczciwy, bo ino jakiegoś człuwieczka zubaczyt (Barbarówka, powiat chełmski);

Bo laleczke i panienke może zobaczyć tylko człowiek prawy, co ma czyste sumienie, a złodziej, krętacz to ino czluwieczka zubaczy (Stryjów, powiat krasnostawski),

a także zmian cywilizacyjnych ostatnich kilkudziesięciu lat, np.:

To czlowieczek, ale i źrenica mówim, ale do pani to lepi powiedzić źrenica, bo człowieczek to tak więcy między sobo mówim (Jabłeczna, powiat bialski);

U nas to człowieczek i źrenica na to mówio, a już w mieście to źrenica bedzie, czluwieczek ni pasuje (Lubień, powiat włodawski).

Latacz // latać 'roślina łąkowa i wodna, Caltha palustris L.' ${ }^{30}$.

Łatacz // łatać funkcjonuje obok nazwy kaczeniec, określając zarówno wygląd rośliny, np.:

Łatacz to kwiaty żólte, co rosno na mokrych łakach, te kwiatki siedzo na takij grubyj i mięsistyj łodydze (Orchówek, powiat włodawski);

Łatacz to żótty kwiat na grubych łodygach (Worgule, powiat bialski), jej trwałość, np.:

Łatacze to one so nitrwate, na tace to ładnie wyglada, a przyniść du domu to zwiędno ud razu (Stary Orzechów, powiat parczewski), jak i miejsce rośnięcia i czas kwitnienia, np.:

Łatać to żólty kwiat, $w$ wodzie prawie rośnie i kwitnie na wiosne (Wołoskowola, powiat włodawski);

Łatacz rośnie na mokrym, a kwitnie wczesno wiosno (Worgule, powiat bialski);

Łatacie rosno na łąkach, dzie jest mokro, ale tera łąi osuszyli, to i łataci mato (Kozły, powiat bialski).

\footnotetext{
29 D. Rembiszewska, J. Siatkowski, op. cit., s. 100; H. Pelcowa, Interferencje..., s. 107, mapa 1.

30 D. Rembiszewska, J. Siatkowski, op. cit., s. 153-155; H. Pelcowa, Interferencje..., s. 133, mapa 27; eadem, Słownik gwar Lubelszczyzny, t. 5: Świat roślin, s. 274, 554, mapa 33.
} 
Korowaj 'tradycyjne, obrzędowe ciasto weselne ozdobione dekoracjami $\mathrm{z}$ ciasta, cukierków, wstążek, kwiatów, pieczone przez korowajnice's1. Kuruwaju nie ma, bo zastapit go tort. Kuruwaju juz nie pieko, bo so torty, a po co kuruwaje, jak wysele nie takie jak kiedys' - tak charakteryzuje 'tradycyjne, obrzędowe ciasto weselne' mieszkanka Terebeli koło Białej Podlaskiej. Inni informatorzy podkreślają wygląd korowaja, a także wskazują na konotacje kulturowe i obyczajowe, np.:

Korowaj to jakby dzisiejszy tort, ale to taki duży byt korowaj i uzdobny bardzo. Szyszkami zdubione te kuruwaje, no ji z takimi wstązeczkami [...]. Szyszki robili. Robiło sie taki ptaszki z tego ciasta, rozcinało sie tędy ogon, tu sie mu robiło główke, dziobek mu sie wkładało, a tu skrzydełka tak mu sie rozcinato. I też sie piekło w piecu (Moniatycze, powiat hrubieszowski); Kurowaj to taki okragty bochenek chleba, przybrany tam czymś, cukierki, szyszki, no i jak mołoduche oczepkaty, to krajały tyn kurowaj i na talerzu każdemu dawały próbować (Sitno, powiat bialski);

Wesele to dawno byt kurowaj, baby zbierali sie i piekli korowaj w piecu. To taki tyn kurowaj wielgi byt i najważniejszy na weselu, to coś jak dzisiaj torty. I żeśmy ten kurowaj przed młodymi stawiali i bez tego ni byto wysela, na każdym weselu kurowaj musiat być [...]. Schodziło sie pare babów, to byli korowajnice [...]. Zbierali sie i piekli korowaj (Brzeźno, powiat chełmski); Korowaja nie każdy mógt piec. Wołało sie starościne i ona robiła ciasto. Potem przystrajała to ciasto różnymi takimi plecionkami, a to gaski jakie, zwierzatka, $i$ wktadata do pieca. Jak sie korowaj piekt to żaden chtop nie mógt wejść do izby, bo to zła wróżba była. Jak już upieczony, to patrzyty wszystkie czy równo wyszedt i czy sie zakalec nie zrobit, bo to też wróżba była. Potem sie korowaja na weselu podawało i wszystkich gości obdzielało. [...]. Korowaja można byto upiec tylko raz, nawet jak sie nie udat, nie można byto nowego robić [...]. A to ważne byto, bo korowaj to jak chleb święty byl, od Pana Boga, którym sie potem dzielili wszyscy. Jak sie korowaj udat duży i tadny to sie mówito, że młodej parze szcześsić sie bedzie, a jak sie nie udat to miało znaczyć klopoty i pecha. Korowaj zawsze musiat być na weselu, żeby młodzi bogato potem żyli (Bytyń, powiat włodawski); Korowaj to byt prezent od staruściny dla moluduchy, a przygotowali go dziń przed wyselem korowajnice, same baby, bo chtopa żadnego nie mogto być przy tym (Witulin, powiat bialski);

Korowaj byto to ciasto lepszego gatunku. Ciasto wyrabiane wktadali do sita, a byt piec chlebowy, ciasto wyrastato ponad sito, nie można go byto wyjąć, czasem nawet aż rozbierali piec (Horodło, powiat hrubieszowski);

\footnotetext{
31 G. Bączkowska, Korowaj, „Etnolingwistyka” 1, 1988, s. 79-99; D. Rembiszewska, J. Siatkowski, op. cit., s. 144-149; H. Pelcowa, Stownik gwar Lubelszczyzny, t. 6: Pokarmy, s. 262265,665 , mapa 16 .
} 
Kuruwaja to pilnowali, bo jakby chto ukrad to bida dla mtodych (Lipnica, powiat bialski).

Nazwa i desygnat głęboko tkwią w strukturze wschodniosłowiańskiej obrzędowości i obyczajowości z odesłaniem do przeszłości (było to ciasto...; ciasto wyrabiali...; kuruwaja pilnowali) i wpisaniem w specyfikę dawnego, tradycyjnego wesela.

Kutia 'potrawa wigilijna z pszenicy, maku i miodu' 32 .

Inaczej jest postrzegana kutia 'potrawa wigilijna $\mathrm{z}$ tłuczonej pszenicy, maku i miodu', która z potrawy ograniczonej terytorialnie stała się na znacznie szerszym obszarze symbolem świąt i kolacji wigilijnej, np.:

Kutia to potrawa wigilijna (Wola Idzikowska, powiat krasnostawski);

Kutia to tak można wyttumaczyć, [...] to je miód, bo miód to stodycz, no to zeby stodko było wszystkim bez caly rok, ale jeszcze mak, pszenica $i$ tam insze, a miód to też stad, że to miłość boska, symbol obfitości, wiecznej szczęśliwości, a mak to ptodność i urodzaj, pszenica to dar życia, bogactwo, urodzaj na zboże, bo to przecież od Boga wszystko dane, takie dary boskie [...] i to taka tradycyjna potrawa je, bo kuti nie można tak pu prostu se ugotować, to sie tylko robi na Wilije, bo to ważna putrawa, to można powiedzić symbol jest (Miętkie, powiat hrubieszowski);

Kutia to tradycyjna potrawa na Wigilie i tak $w$ roku to sie ji nie gutuje, tylko na Wigilie, bo to ważna potrawa, taki symbol świąt jest, narodzenia Jezusa. No bo to skucia sie tam tyn pęcak, pszenice niby, mak obowiazkowo, miód. Ale to w innych strunach ty kuti nie gutujo, ale tu tylko u nas, bo tu ta tradycja sie zachowuje (Borowiec, powiat biłgorajski).

W większości wypowiedzi jest odesłanie do przeszłości (kutie podawali...; kutie podrzucali do góry...; kutie sie obowiazkowo gotowato...), ale niezależnie od tego, nazwa i desygnat są w pełni rozpoznawalne, a także poświadczone we współczesnej rzeczywistości: ja i tera kutii sobie kupie na Wigilie, bo sama już ni robie (Łukowa, powiat biłgorajski). Ginie tylko aspekt symboliczny i magiczny, z przepowiadaniem przyszłości i urodzaju, bardzo wyraźnie ujawniający się w odniesieniu do przeszłości, np.:

Pierszo kutie podawali, bo jak kutia była to byt znak, że urodzaj bedzie. To byta najwazniejsza potrawa podczas wieczerzy. A to sie brato troche gotowanej pszenicy, mak sie $w$ dunicy wiercito, potem to wszysko sie mieszało, miodu, orzechów można było dodać. I taka kutia było. Potem to sie brało na tyzki i rzucało sie do sufitu i patrzyło sie ile ziaren sie przyczepi, im więcyj tym lepij. Byla to potrawa nie tylko smaczna, ale także $i$ zwia-

32 F. Czyżewski, Atlas..., mapa 86; H. Pelcowa, Słownik gwar Lubelszczyzny, t. 6: Pokarmy, s. 297-299, 664, mapa 15; J. Reichan, Wyraz kutia w gwarach polskich, „Roczniki Humanistyczne KUL” XXXVI, 1998, z. 7, s. 45-56. 
stująca dustatnie życie, bo pszenica oznaczała sytość, mak urodzaj, miód słodycz w życiu (Putnowice Wielkie, powiat chełmski);

Kutie podrzucali du pułapu, żeby kunie ni chorowali i dobrze brykali (Łyniew, powiat bialski).

Z przedstawionych, z konieczności wybranych, przykładów wyłania się obraz słownictwa kresowego, głęboko osadzonego w symbolice, magii i tradycji ludowej pogranicza kulturowego i geograficznego. Słowa pogranicza nazywają zarówno dawne, jak i obecnie funkcjonujące desygnaty, z zasięgami zlokalizowanymi:

1) na całym obszarze Lubelszczyzny wschodniej, np. koromysto - na północy i koromysta - na południu Lubelszczyzny wschodniej, bettun // bottun, cedziłko, cepilno, człowieczek, kosowica, krynica, loch, łatacz // tatać, makutra, ożyny, pieweń // piewnik, raby, radno, snozy // snózki, tok; są to najliczniejsze poświadczenia, a kresowizmy stanowią na tym terenie około $60 \%$ gwarowego zasobu leksykalnego;

2) na Lubelszczyźnie wschodniej z zasięgiem rozszerzającym się w części południowej na dawne województwa bełskie i ruskie (z dzisiejszym powiatem biłgorajskim), a także Lubelszczyznę środkową i częściowo zachodnią, np. bodziak // bodak // bodiak, chusty, dryga i formy pokrewne, kociuba, kutia, korowaj (w formie zmienionej korowal także w części środkowej i zachodniej województwa lubelskiego), lepiech, słoducha // sołoducha, sudki, zezula i formy pokrewne;

3) w północnej części Lubelszczyzny wschodniej, np. berdo, kruczek, kwaszeliny, młodziwo // mołodziwo // mołoziwo, urzech, żłukto;

4) na południowym i środkowym wschodzie regionu lubelskiego, z zasięgami sięgającym także w zachodnią część Lubelszczyzny południowej, np. kopanice, maniak, świerzupa, zolnik, żmykać.

To wskazuje, że najbardziej nasycone kresowizmami, powiązanymi genetycznie i geograficznie z gwarami wschodniosłowiańskimi, są wsie nadbużańskie, chociaż zasięgi wielu wyrazów kresowych obejmują także Lubelszczyznę południową i środkową.

\section{BIBLIOGRAFIA}

Arkušin Grigorìj. 2000. Slovnik zahidniopolis'kih govirok t. 1-2. Luc'k: Volins'kij deržavnij unìversitet im. Lesì Ukraïnki. [Аркушин Григорій. 2000. Словник західнополіських говірок т. 1-2. Луцьк: Волинський державний університет іm. Лесі Українки].

Atlas ukraïns'koї movi t. 1-2. 1984-1988. Kï̈v [Атлас украӥнської мови т. 1-2. 1984 1988. Київ].

Bartmiński Jerzy. 2007. Czym zajmuje się etnolingwistyka?. J. Bartmiński. Stereotypy mieszkaja w języku. Studia etnolingwistyczne. Lublin: Wydawnictwo UMCS: 32-39.

Bączkowska Grażyna. 1988. Korowaj, „Etnolingwistyka” 1: 79-99. 
Czyżewski Feliks. 1986. Atlas gwar polskich i ukrainskich okolic Włodawy. Lublin: Wydawnictwo UMCS.

Czyżewski Feliks. 1988. O problemach interferencji językowej w ukraińskich gwarach wschodniej Lubelszczyzny. „Z Polskich Studiów Slawistycznych”. Seria VII. Językoznawstwo: 87-93.

Czyżewski Feliks. 2018. Kilka uwag leksykograficznych (na marginesie Słownika gwar zachodniopoleskich Hryhorija Arkuszyna). „Poznańskie Studia Polonistyczne. Seria Językoznawcza”. vol. 25 (45), nr 1: 33-44.

Dejna Karol. 1984. W sprawie tzw. dialektów kresowych, „Język Polski” 64: 51-57.

Doroszewski Witold. 1958. Red. Stownik jezyka polskiego t. 1. Warszawa: Państwowe Wydawnictwo Naukowe.

Gala Sławomir. Gala-Milczarek Beata. 2006. Jeszcze w sprawie metodyki badań pogranicza językowego. W: Spotkania polsko-ukraińskie. Język - Kultura - Literatura. Red. Pelcowa H. Chełm: Wydawnictwo PWSZ: 141-149.

Karaś Halina. 2017. Język polski pogranicza litewsko-łotewsko-białoruskiego w świetle frekwencji cech jezzykowych. Warszawa: Wydawnictwo Uniwersytetu Warszawskiego.

Kostecka-Sadowa Anna. 2015. Rzeczownikowe zapożyczenia wschodniostowiańskie w gwarach polskich. Kraków: Prace Instytutu Języka Polskiego PAN.

Kość Józef. 1999. Polszczyzna poludniowokresowa na polsko-ukraińskim pograniczu językowym w perspektywie historycznej. Lublin: Wydawnictwo UMCS.

Kuraszkiewicz Władysław. 1932. Przegląd gwar województwa lubelskiego. W: Monografia statystyczno-gospodarcza województwa lubelskiego t. 1. Lublin: 273-324.

Kurzowa Zofia. 1983. Polszczyzna Lwowa i kresów poludniowo-wschodnich do 1939 roku. Warszawa-Kraków: Państwowe Wydawnictwo Naukowe.

Kurzowa Zofia. 1985. O polskich dialektach kresowych. „Język Polski” 65: 98-108.

Leksičny atlas belaruskih harodnyh gavorak t. 1-2. 1993-1994. Minsk: Akadèmiâ Navuk Belarusì. [Лексічны атлас беларускіх хародных гаворак т. 1-2. 1993-1994. Мінск: Акадэмія Навук Беларусі].

Łesiów Michał. 1978. Polsko-ukraińskie oboczności leksykalne w gwarach pogranicza. „Z Polskich Studiów Slawistycznych” seria V. Językoznawstwo: 279-286.

Mazur Jan. 1976-1978. Gwary okolic Bitgoraja. Cz. 1. Fonologia. Cz. 2. Fleksja, Wrocław: Zakład Narodowy im. Ossolińskich.

Obŝeslavânskij lingvističeskij atlas. Vypusk I. Životnyj mir. Moskva: „NAUKA”. [Общеславянский лингвистический атлас. Выпуск І. Животный мир. Москва: „НАУКА”].

Pelcowa Halina. 1993. Gtos $w$ dyskusji nad gwarami przejściowymi i mieszanymi wschodniej Polski. W: Studia nad polszczyzna kresowa t. 7. Red. Rieger J. Wrocław: Zakład Narodowy im. Ossolińskich: 159-169.

Pelcowa Halina. 1994. Mazowizmy leksykalne w gwarach Lubelszczyzny. Lublin: Wydawnictwo UMCS.

Pelcowa Halina. 1997. Stownictwo wschodniostowiańskie w gwarach Polski środkowo-wschodniej w świetle związków językowych polsko-ukraińskich. W: Ze studiów nad gwarami wschodniostowiańskimi w Polsce. „Rozprawy Slawistyczne” 12. Red. Czyżewski F., Łesiów M. Lublin: Wydawnictwo UMCS: 189-211.

Pelcowa Halina. 2001. Interferencje leksykalne w gwarach Lubelszczyzny. Lublin: Wydawnictwo UMCS.

Pelcowa Halina. 2001. Kulturowa wartość słownictwa w gwarach pogranicza (na przykładzie gwar wschodniolubelskich). W: Język i kultura na pograniczu polsko-ukraińsko-białoruskim. Red. Czyżewski F. Lublin: Wydawnictwo UMCS: 43-59. 
Pelcowa Halina. 2001. Polsko-białorusko-ukraińskie paralele leksykalne $w$ świetle kulturowego dziedzictwa prastowiańskiego. W: Język i kultura białoruska w kontakcie z sasiadami. Red. Smułkowa E., Engelking A. Warszawa: Wydział Polonistyki UW: 141-151.

Pelcowa Halina. 2012. Stownictwo kresowe jako element tożsamości pogranicza (na materiale gwar Lubelszczyzny). W: Polskie dziedzictwo językowe na dawnych Kresach. Język polski dawnych Kresów Wschodnich t. 5. Red. Dzięgiel E., Czarnecka K., Kowalska D. Warszawa: Wydawnictwo Naukowe Semper: 257-264.

Pelcowa Halina. 2015. Dziedzictwo leksykalne pogranicza polsko-wschodniostowiańskiego w interpretacji mieszkańców wsi. W: Pogranicza słowiańskie w opisach językoznawczych. W 110 rocznice urodzin Profesora Władysława Kuraszkiewicza (1905-1997). Red. Czyżewski F., Olejnik M., Pihan-Kijasowa A. Lublin-Włodawa: Wydawnictwo Polihymnia: 91-98.

Pelcowa Halina. 2015. Nazwa i desygnat $w$ zmieniajacej się rzeczywistości wiejskiej. W: Odkrywanie stowa - historia i wspótczesność. Red. Sokólska U. Białystok: Wydawnictwo Uniwersytetu w Białymstoku: 551-568.

Pelcowa Halina. 2015. Słownik gwar Lubelszczyzny t. 3. Świat zwierząt. Lublin: Wydawnictwo UMCS.

Pelcowa Halina. 2016. Stownik gwar Lubelszczyzny t. 4. Sad i ogród warzywny. Budownictwo i przestrzeń podwórza. Lublin: Wydawnictwo UMCS.

Pelcowa Halina. 2017. Stownik gwar Lubelszczyzny t. 5. Świat roślin. Lublin: Wydawnictwo UMCS.

Pelcowa Halina. 2019. Stownik gwar Lubelszczyzny t. 6. Pokarmy. Lublin: Wydawnictwo UMCS.

Pihan-Kijasowa Alicja. 2015. Polszczyzna Kresów Wschodnich-efekt pogranicza językowego. W: Pogranicza słowiańskie w opisach językoznawczych. W 110 rocznice urodzin Profesora Władystawa Kuraszkiewicza (1905-1997). Red. Czyżewski F., Olejnik M., Pihan-Kijasowa A. Lublin-Włodawa: Wydawnictwo Polihymnia: 97-104.

Reichan Jerzy. 1998. Wyraz kutia w gwarach polskich, „Roczniki Humanistyczne KUL” 36. z. 7: 45-56.

Rembiszewska Dorota, Siatkowski Janusz. 2018. Pogranicze polsko-wschodniosłowiańskie. Studia wyrazowe. Warszawa: Wydział Polonistyki UW.

Rieger Janusz. 1997. Interferencje ukraińskie w gwarach polskich na Podolu. W: Interferencje w językach i dialektach słowiańskich. Red. Umińska-Tytoń E. Łódź: Wydawnictwo ŁTN: 134-140.

Rieger Janusz. 2008. Red. Stownictwo kresowe. Studia i materiały. Warszawa: Wydawnictwo DiG.

Walczak Bogdan. 2015. Pogranicze polsko-wschodniosłowiańskie od średniowiecza do dziś, W: Pogranicza słowiańskie w opisach językoznawczych. W 110 rocznicę urodzin Profesora Władysława Kuraszkiewicza (1905-1997). Red. Czyżewski F., Olejnik M., Pihan-Kijasowa A. Lublin-Włodawa: Wydawnictwo Polihymnia: 149-156.

Warchoł Stefan. 1992. Specyfika gwar mieszanych i przejściowych na terenach etnicznie zróżnicowanych. Rozprawy Slawistyczne 5. Lublin: Wydawnictwo UMCS. 


\title{
BORDERLANDS VOCABULARY \\ (BASED ON THE DIALECT MATERIAL FROM THE EASTERN PART OF THE LUBLIN REGION)
}

Summary. The study deals with the geographically, mentally and historically motivated vocabulary of the eastern part of the Lublin region as seen through the prism of the name-designatum relationship and the globalization-related civilization and cultural changes. The vocabulary includes: (1) names of East Slavic provenance, including words and their meanings of the Ukrainian and Belorussian origin; (2) geographically-restricted dialectal borderlands forms common for the formations of the Eastern Borderlands linguistic community alongside the Bug river; (3) words functioning in the villagers' linguistic awareness of a given national community.

Key words: word, Borderlands, dialects, the Lublin region

\section{СЛОВА ПОГРАНИЧЧЯ \\ (НА ДІАЛЕКТНОМУ МАТЕРІАЛІ СХІДНОЇ ЛЮБЛІНЩИНИ)}

\begin{abstract}
Анотація. Предметом дослідження є лексика, яка в географічному, ментальному та історичному вимірі пов'язана з територією східної Люблінщини; вона розглядається у відношенні до десигната і цивілізаційно-культурних змін, що випливають із глобалізаційних процесів. Сюди належать: 1) генетично східнослов'янські лексеми, тобто слова (або їхні значення) українського, білоруського походження; 2) георгафічні периферійні діалектизми, спільні для говорів східного пограниччя по обидва боки Західного Бугу, причому ця спільність пов'язана виключно із територіальним сусідством; 3) лексеми, що функціонують у мовній свідомості мешканців села як властиві окресленій нації.
\end{abstract}

Ключові слова: лексема, пограниччя, говірки, Люблінщина 
